\title{
In Vivo Regulation of Glycolytic and Gluconeogenic Enzyme Gene Expression in Newborn Rat Liver
}

\author{
Stanislas Lyonnet, ${ }^{\star 5}$ Christine Coupé, ${ }^{\star}$ Jean Girard, ${ }^{\ddagger}$ Axel Kahn, ${ }^{\star}$ and Amold Munnich ${ }^{\star 5}$ \\ *Institut National de la Santé et de la Recherche Médicale U129, Unité de Génétique et Pathologie Moléculaires, 75014 Paris, France; \\ ${ }^{\ddagger}$ Centre de Recherches sur la Nutrition, 92190 Meudon-Bellevue; and ${ }^{\S}$ Institut National de la Santé et de la Recherche Médicale U12, \\ Unité de Recherches de Génétique Médicale, 75015 Paris, France
}

\begin{abstract}
Glucagon and its second messenger, cAMP, are known to rapidly block expression of the L-type pyruvate kinase gene and to stimulate expression of phosphoenolpyruvate (PEP) carboxykinase gene in the liver in vivo. The respective roles, however, of hyperglucagonemia, insulinopenia, and carbohydrate deprivation in the inhibition of L-type pyruvate kinase gene expression during fasting are poorly understood. In addition, the long-term effects of physiological hyperglucagonemia on expression of the two genes are not known.

In this study, we investigate the effects of long-term physiological hyperglucagonemia and insulinopenia induced by suckling (which provides a high-fat, low-carbohydrate diet) on expression of the two genes in the liver of normal newborn rats.

We show that transcription of the L-type pyruvate kinase gene is inhibited at birth and remains low during the whole suckling period, whereas transcription of the PEP carboxykinase gene is maximal in the neonate, and then decreases despite very high levels of plasma glucagon during suckling.

In contrast to the adult, however, in which L-type pyruvate kinase gene expression in the liver is blocked by cAMP and stimulated by carbohydrates, the regulation of L-type pyruvate kinase gene expression in the newborn undergoes a developmental maturation: the inhibitory effect of glucagon is never complete in developing rat liver and the stimulatory effect of glucose could not be detected during suckling, due to either hyperglucagonemia, immaturity of the gene regulatory system, or both.
\end{abstract}

\section{Introduction}

L-type pyruvate kinase (ATP:pyruvate $\mathrm{O}^{2}$-phosphotransferase, EC 2.7.1.40) and the cytosolic form of phosphoenolpyruvate $(\mathrm{PEP})^{1}$ carboxykinase (guanosine $5^{\prime}$ triphosphate; EC 4.1.1.32) are key enzymes in the glycolytic and gluconeogenic pathways, respectively, whose activities fluctuate greatly according to the dietary status of the liver. A carbohydrate-rich diet stimulates

Address reprint requests to Dr. Stanislas Lyonnet, INSERM U12, Unité de Génétique Medicale, Hôpital NecKer-Enfants Malades 149, rue de Sèvres, 75743 Paris Cédéx 15, France.

Received for publication 13 July 1987 and in revised form 30 November 1987.

1. Abbreviations used in this paper: $\mathrm{Bt}_{2} \mathrm{CAMP}, \mathrm{N}^{6}, \mathrm{O}^{2}$-dibutyryl cAMP; PEP, phosphoenolpyruvate; SSC, standard saline citrate.

J. Clin. Invest.

(c) The American Society for Clinical Investigation, Inc.

$0021-9738 / 88 / 06 / 1682 / 08 \$ 2.00$

Volume 81, June 1988, 1682-1689 the expression of the glycolytic enzyme gene and blocks that of the gluconeogenic enzyme gene. Conversely, fasting or feeding normal rats a protein-rich diet results in the blockade of glycolytic enzyme gene expression, whereas that of the gluconeogenic enzyme gene is switched on (1-3).

The expression of both genes is controlled by two antagonistic pancreatic hormones, insulin and glucagon, which affect both the glycolytic and the gluconeogenic pathways at different levels of gene expression. Glucagon, for instance, rapidly blocks transcription of the L-type pyruvate kinase gene, shortens the $t_{1 / 2}$ of its mRNA, and inactivates the mature enzyme by phosphorylation via its second messenger, cAMP (4-9). Glucagon simultaneously switches on the transcription of the PEP carboxykinase gene so as to produce an increase in glucose production by the liver during fasting (10-12). Conversely, insulin blocks the transcription of the PEP carboxykinase gene and is required for full expression of the L-type pyruvate kinase gene in carbohydrate-fed rats $(13,14)$. The effects of glucagon and insulin on the two metabolic pathways thus are both concerted and integrated at the transcriptional and the posttranscriptional levels in the liver. To date, however, the respective roles of hyperglucagonemia, insulinopenia, and low-carbohydrate diet on the inhibition of L-type pyruvate kinase gene expression in the liver in vivo are poorly understood. In addition, the long-term effect of physiological hyperglucagonemia on expression of the two genes remains questionable.

In this study, we investigated the long-term effects of suckling-induced physiological hyperglucagonemia and insulinopenia on gene expression in normal newborn rats. The data presented here suggest that the PEP carboxykinase gene is fully responsive to the glucagon burst that occurs at birth, although later the gene seems to escape its positive effector.

Expression of the L-type pyruvate kinase gene is strongly inhibited at birth and remains low during the whole suckling period. Moreover, glucose feeding does not adequately trigger gene expression, nor does glucagon fully inhibit the mRNA accumulation in suckling rats. The regulation of L-type pyruvate kinase gene expression thus might undergo a developmental maturation, because induction by glucose is absent and inhibition by glucagon is only partial in developing rat liver, just as in adult rat kidney and small intestine (15).

\section{Methods}

\section{Materials}

Chemicals of the highest purity available were obtained from Merck, Sharp, \& Dohme, Div., West Point, PA, Serva Fine Biochemicals, Garden City Park, NY, Sigma Chemical Co., St. Louis, MO, Difco Laboratories, Inc., Detroit, MI, Pharmacia Fine Chemicals, Inc., Piscataway, NJ, and Boehringer-Mannheim Diagnostics, Indianapolis, 
IN. $\mathrm{N}^{6}, \mathrm{O}^{2}$-Dibutyryl cAMP $\left(\mathrm{Bt}_{2}\right.$ cAMP) was from Sigma Chemical Co., polyose MD25 from Guigoz France S.A., (Courbevoie, France) nitrocellulose paper (BA85) from Schleicher \& Schuell, Inc., Keene, NH, nylon Gene Screen Plus filters from New England Nuclear, Boston, MA, and nylon Highbond-N filters from Amersham Corp., Arlington Heights, IL. Formamide and formaldehyde were purchased from Merck and methylmercury hydroxide from Ventron Alfa Products (Karlsruhe, FRG) $\left(\alpha^{32} \mathrm{P}\right) \mathrm{dCTP}(3,000 \mathrm{Ci} / \mathrm{mmol})$ and $\left(\alpha^{32} \mathrm{P}\right) \mathrm{UTP}$ $(>400 \mathrm{Ci} / \mathrm{mmol}$ ) were supplied by Amersham Corp. and Biofluor by New England Nuclear. Restriction enzymes and DNA polymerase large fragment according to Klenow were obtained from Amersham Corp. DNase 1, RNase, proteinase K, S1 nuclease, and nucleotides were from Boehringer-Mannheim. Multiprime DNA labeling system was obtained from Amersham Corp. and cell-free translation system from New England Nuclear. Royal X-Omat films were purchased from Eastman Kodak.

\section{Animals}

Animals were Wistar rats that were bred in the Centre de Recherches sur la Nutrition (Meudon-Bellevue). Fetuses were obtained by caesarean sections at 15,18 , and $20 \mathrm{~d}$ after cohception. Term newborns were obtained either by cesarean section $21 \mathrm{~d}$ after conception or by normal delivery. Suckling animals were left with the mother until further experiments were performed. On day 5 or 10 , each litter was split into four groups: controls, fasted rats, cAMP-injected rats, and glucose-fed rats. Control animals were injected subcutaneously with $9 \mathrm{~g} /$ liter sodium chloride and left with the mother. Fasted rats were separated from the mother after sodium chloride injection and kept in a homeothermic environment. cAMP-treated rats were injected with $10 \mu \mathrm{g}$ of $\mathrm{Bt}_{2} \mathrm{cAMP} / \mathrm{g}$ body weight and left with the mother. $\mathrm{Bt}_{2} \mathrm{cAMP}$ or sodium chloride injections were repeated each $180 \mathrm{~min}$ for $10 \mathrm{~h}$ (time $0,3,6$, and $9 \mathrm{~h}$ ) and the rats were killed $1 \mathrm{~h}$ after the last injection. Glucose-fed rats were force-fed a high carbohydrate liquid diet containing $60 \%$ glucose and $40 \%$ maltose, dextrins, and polyoses (volume: 120 and $200 \mu \mathrm{l}$ for 5- and 10-d-old rats, respectively) every $3 \mathrm{~h}$ for $10 \mathrm{~h}$.

Finally, some control rats had free access to the mother's diet from day 15 and were weaned to the stock chow diet at day 18. Dams were fed a stock chow diet including carbohydrate (65\% of total calories), fats $(11 \%)$, and proteins (24\%).

All rats were decapitated and blood was taken for blood glucose and hormone determinations. Blood glucose was determined by the glucose oxidase method. Plasma glucagon and insulin were measured by RIA (Biodata Laboratory, Rome, Italy). The liver was immediately removed, weighed, and homogenized for subsequent nuclei isolation or RNA extractions. Liver cAMP was assayed using the cAMP (125) assay system from Amersham Corp. after homogenization of frozen liver samples in $2 \mathrm{~N}$ perchloric acid and neutralization by $3 \mathrm{M} \mathrm{KOH}, 3$ $\mathrm{M} \mathrm{K}_{2} \mathrm{Cl}_{3}$.

\section{Experimental procedures}

Total RNA purification. Total cellular RNAs were extracted by ethanol precipitation in guanidinium $\mathrm{HCl}$ as described previously (16) and quantitated by both spectrophotometry and gel analysis. Integrity of the RNA preparations was analyzed systematically by electrophoresis and visualization of $18 \mathrm{~S}$ and $28 \mathrm{~S}$ ribosomal RNAs by ethidium bromide staining. The $28 \mathrm{~S} / 18 \mathrm{~S}$ ratio was always close to 2 , without any detectable low molecular weight forms.

Cell-free translation of L-type pyruvate kinase mRNA. Polyadenylated RNAs were isolated by chromatography on oligo(dT)-cellulose (17) and mRNAs were translated in vitro in a rabbit reticulocyte cellfree lysate system (18). Polypeptides synthesized in vitro were purified by immunoaffinity chromatography using anti-rat L-type pyruvate kinase antibodies (19) and analyzed by SDS-PAGE (20). Protein bands were detected by autoradiography.

Northern blot analysis and quantitation of MRNA by dot blot procedure. Total RNA was denatured in $10 \mathrm{mM}$ methylmercury hydroxide for $10 \mathrm{~min}$ at $20^{\circ} \mathrm{C}$, and then applied to a $1.5 \%$ agar gel containing $10 \mathrm{mM}$ methylmercury hydroxide in a $5-\mathrm{mM}$ sodium tetraborate buffer, $10 \mathrm{mM}$ sodium sulfate, $1 \mathrm{mM}$ EDTA, and $50 \mathrm{mM}$ boric acid (pH 8.2), and separated by electrophoresis for $12 \mathrm{~h}(21)$. The gel was washed and transferred onto a filter in $20 \times$ standard saline citrate (SSC) $(1 \times \mathrm{SSC}=0.15 \mathrm{M} \mathrm{NaCl}$ and $0.015 \mathrm{M}$ Tris-sodium citrate) and left for at least $12 \mathrm{~h}(22)$. The filters were then baked and hybridized.

The dot-blot procedure was used for measuring specific mRNA concentration (23). Nitrocellulose filters were prewet in sterile water, then soaked in 20× SSC and allowed to dry in air. Total RNA was diluted in $10 \mathrm{mM}$ phosphate buffer ( $\mathrm{pH} 7.4$ ), and its concentration checked by measuring $0 . d$. at $260 \mathrm{~nm}$. Then, RNA was denatured in $2.2 \mathrm{M}$ formaldehyde for $10 \mathrm{~min}$ at $65^{\circ} \mathrm{C} .6 \mu \mathrm{g}$ of RNA and five subsequent 1:2 dilutions in $10 \mathrm{mM}$ phosphate buffer (pH 7.4) and $2.2 \mathrm{M}$ formaldehyde were dotted onto nitrocellulose filters. The hybridization was performed in the presence of $2 \times 10^{6} \mathrm{cpm} / \mathrm{ml}$ of labeled probe ( $0.5 \mathrm{ml}$ of hybridization mixture per $10 \mathrm{~cm}^{2}$ of filter surface). The results were either expressed in counts per minute of probe hybridized per $3 \mu \mathrm{g}$ of RNA dotted or in integration units by scanning the autoradiograms using a densitometer (Shimadzu Seisakusho, Ltd., Kyoto, Japan). Assay blanks were prepared using RNAs derived from two organs devoid of L-type pyruvate kinase (spleen and lung); the radioactivity counted in blanks was approximately zero. The intensity of mRNA bands on the Northern blots was measured by scanning the autoradiograms using a densitometer (Shimadzu Seisakusho, Ltd.).

The cDNA for rat liver L-type pyruvate kinase mRNA has been cloned in our laboratory $(25,26)$. A 388-bp Taq 1-Pst 1 restriction fragment corresponding to the last 144 coding nucleotides and to the first 244 3' noncoding nucleotides was subcloned into the single-strand phage M 13 (26). The recombinant phage was used as template for the synthesis of the complementary strand in the presence of deoxynucleotides including a limiting amount of $\left(\alpha^{32} \mathrm{P}\right) \mathrm{dCTP}$. After strand separation, a highly labeled probe was obtained whose specific activity was $\sim 10^{9} \mathrm{cpm} / \mu \mathrm{g}$ DNA (27). The full-length cDNA probe for rat liver cytosolic PEP carboxykinase mRNA (PCK 10, 2,400 bp, reference 28) was provided by Richard W. Hanson (Department of Biochemistry, Case Western Reserve University School of Medicine, Cleveland, $\mathrm{OH}$; references 21 and 22) and labeled by random hexamer priming (specific activity: $2 \times 10^{9} \mathrm{dpm} / \mu \mathrm{g}$ insert, reference 29 ). The filters were hybridized as previously described $(21,22)$ at $65^{\circ} \mathrm{C}$ in $3 \times$ SSC with $3 \times$ $10^{6} \mathrm{cpm} / \mathrm{ml}$ of probe and $0.5 \mathrm{ml} / 10 \mathrm{~cm}^{2}$ of hybridization mixture. The final wash was at $65^{\circ} \mathrm{C}$ in $0.2 \times \mathrm{SSC} / 1 \% \mathrm{SDS}$.

In vitro transcription on isolated nuclei. The elongation of nascent RNA transcripts on the L-type pyruvate kinase and PEP carboxykinase genes was measured by run-on transcription assay on isolated nuclei. This experiment is a method of investigating the in vivo rate of transcription of a specific gehe at the time of killing. The in vitro initiation of new transcripts in isolated nuclei is inefficient, so that labeled RNAs only reflect the in vitro elongation of RNA molecules whose synthesis has been initiated in vivo under the conditions studied $(30,31)$.

Nuclei were prepared according to Schibler's procedure (32). $2 \mathrm{~g}$ of liver was homogenized in $20 \mathrm{ml}$ of ice-cold $0.3 \%$ sucrose in a motordriven Potter-Elvehjem homogenizer (Kontes, Vineland, NJ). The homogenate was filtered through strips of cheesecloth, layered over a $30 \%$ sucrose cushion $(20 \mathrm{ml})$ and spun for $20 \mathrm{~min}$ at $600 \mathrm{~g}$. The nuclear pellet was resuspended in $2 \mathrm{M}$ sucrose $(6 \mathrm{ml})$, layered onto a 2-M sucrose cushion $(6 \mathrm{ml})$ and spun for $1 \mathrm{~h}$ at $36,000 \mathrm{rpm}$ at $4^{\circ} \mathrm{C}$. This procedure yielded $\sim 10^{8}$ nuclei per gram of liver. Isolated nuclei were resuspended in $20 \mathrm{mM}$ Tris (pH 7.9), $75 \mathrm{mM} \mathrm{NaCl}, 0.5 \mathrm{mM}$ EDTA, $0.85 \mathrm{mM}$ DTT, $0.125 \mathrm{mM}$ PMSF, and 50\% glycerol and stored at $-70^{\circ} \mathrm{C}$.

For transcription, $8 \times 10^{6}$ nuclei were incubated in $200 \mu \mathrm{l}$ reaction mixture containing $20 \%$ glycerol, $20 \mathrm{mM}$ Tris (pH 7.9), $50 \mathrm{mM} \mathrm{NaCl}$, $4 \mathrm{mM} \mathrm{MnCl}_{2}, 0.5 \mathrm{mM}$ aurintricarboxylic acid, $0.35 \mathrm{M}\left(\mathrm{NH}_{4}\right)_{2} \mathrm{SO}_{4}, 1.2$ $\mathrm{mM}$ DTT, $0.1 \mathrm{mM}$ PMSF, $10 \mathrm{mM}$ creatine phosphate, $1 \mathrm{mg} / \mathrm{ml}$ heparin sulfate, $500 \mathrm{U} / \mathrm{ml}$ RNAsine, $1 \mathrm{mM}$ ATP, guanosine $5^{\prime}$ triphosphate and cytidine $5^{\prime}$ triphosphate, and $250 \mu \mathrm{Ci}$ of $\left(\alpha^{32} \mathrm{P}\right)$ uridine $5^{\prime}$ triphosphate $(410 \mathrm{Ci} / \mathrm{mmol})$ at $30^{\circ} \mathrm{C}$ for $30 \mathrm{~min}(4)$. Then, $0.03 \mathrm{mg} / \mathrm{ml}$ pro- 
teinase $\mathrm{K}$ and DNAse 1 were added and the sample was incubated at $37^{\circ} \mathrm{C}$ for $30 \mathrm{~min}$.

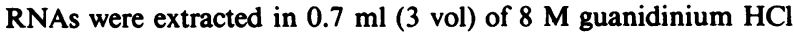
(pH 5.0) containing $20 \mathrm{mM}$ sodium acetate, $10 \mathrm{mM}$ iodoacetate, and $0.5 \%$ (wt/vol) lauryl sarcosine, and precipitated by addition of $0.6 \mathrm{vol}$ ethanol for $12 \mathrm{~h}$ at $-20^{\circ} \mathrm{C}$. After centrifugation at $15,000 \mathrm{rpm}$ at $-10^{\circ} \mathrm{C}$ for $30 \mathrm{~min}$, the pellet was redissolved twice in $0.5 \mathrm{ml}$ guanidinium $\mathrm{HCl}(7 \mathrm{M})(\mathrm{pH} 7.0)$, and allowed to precipitate in $0.6 \mathrm{vol}$ ethanol at $\mathrm{pH} 5.0$ for $2 \mathrm{~h}$ at $-20^{\circ} \mathrm{C}$. After centrifugation, the pellet was dried and then dissolved in the hybridization mixture and the RNAs were denatured for $10 \mathrm{~min}$ at $65^{\circ} \mathrm{C}$.

Transcripts containing the glycolytic or gluconeogenic enzyme sequences were quantitated by hybridization to Gene Screen Plus (New England Nuclear) filter disks containing recombined pBR plasmids. Plasmids $(6 \mu \mathrm{g})$ that were complementary to L-type pyruvate kinase, PEP carboxykinase, and albumin (33) genes were immobilized on 5 -mm-diam filters. The hybridization mixture of $200 \mu \mathrm{l}$ contained $50 \%$ formamide, $1 \%$ glycine, $2.4 \%$ SDS, $10 \times$ Denhardt's, $3 \times$ SSC, 100 $\mu \mathrm{g} / \mathrm{ml}$ poly A, $200 \mu \mathrm{g} / \mathrm{ml}$ salmon DNA, $0.5 \mathrm{mg} / \mathrm{ml} \mathrm{A} \mathrm{-} \mathrm{muscle} \mathrm{RNA,}$ and from 1.5 to $2.5 \times 10^{7} \mathrm{cpm}$ of the labeled RNA sequences. The hybridization mixture was overlayered with mineral oil and incubated at $42^{\circ} \mathrm{C}$ for $48 \mathrm{~h}$. The filters were washed three times with $1 \times \mathrm{SSC} / 1 \%$ SDS at $65^{\circ} \mathrm{C}$ for $45 \mathrm{~min}$ each, treated for $1 \mathrm{~h}$ at $37^{\circ} \mathrm{C}$ in $1 \times \mathrm{SSC}$ containing $60 \mu \mathrm{g} / \mathrm{ml}$ proteinase $\mathrm{K}$, then washed again with $0.5 \times$ $\mathrm{SSC} / 1 \% \mathrm{SDS}$ for $1 \mathrm{~h}$ at $65^{\circ} \mathrm{C}$. After autoradiographic exposure, the filters were washed twice with $1 \times \mathrm{SSC}$ for $30 \mathrm{~min}$ at $65^{\circ} \mathrm{C}$, digested for $30 \mathrm{~min}$ at $37^{\circ} \mathrm{C}$ in $1 \times \mathrm{SSC}$ containing $10 \mu \mathrm{g} / \mathrm{ml} \mathrm{RNAse} \mathrm{A}$, and then washed twice with $1 \times \mathrm{SSC}$ for $30 \mathrm{~min}$ at $37^{\circ} \mathrm{C}$. After a final autoradiographic exposure, radioactivity was eluted from the filters with $0.1 \times$ SSC $/ 0.1 \%$ SDS for $3 \mathrm{~min}$ at $100^{\circ} \mathrm{C}$ and counted by liquid scintillation.

All the values are given after subtraction of the blank, i.e., nonspecific hybridization to nonrecombined plasmids. The level of the blank was usually very low, $<50 \mathrm{cpm}$. Transcription rates, expressed as parts per million, were calculated from the following equation: specific counts per minute eluted from the filters/total counts per minute of radiolabeled RNA $\times 100 /$ hybridization efficiency $\times$ length of the gene/length of the cDNA insert in basepairs. This corrects for the size of cDNA probe relative to gene length and for the efficiency of hybridization, which averaged $40 \%$. The L-type pyruvate kinase gene is $10 \mathrm{~kb}$ long, and we have used two overlapping CDNA clones covering $2.1 \mathrm{~kb}$ of the mRNA sequence (25). The PEP carboxykinase and albumin genes are 6 and $15 \mathrm{~kb}$ long, respectively. The DNA probes for runon assays were 2,400 and 1,000 bp for PEP carboxykinase and albumin, respectively $(28,33)$.

\section{Results}

Physiological parameters in the animals studied. In term fetuses, plasma glucagon was low as compared with that of newborn rats, but it rose twofold within the first hours of life and remained high during the whole suckling period (Table I); while plasma insulin was high at birth, it decreased immediately after birth and remained low during the suckling period. The plasma insulin/glucagon molar ratio thus fell from 9.5 in fetuses at term to 0.9 at $6 \mathrm{~h}$ and remained low from day 1 to day 15 (mean ratio $\pm 1 \mathrm{SD}=1.2 \pm 0.4$ ). In the 22 -d-old weaned animals, plasma glucagon decreased to $61 \pm 15 \mathrm{pg} / \mathrm{ml}$, while the insulin/glucagon molar ratio rose $(5 \pm 0.5)$ to average adult values. These values are mean $\pm 1 \mathrm{SD}$ for at least seven different animals (Table I).

Total liver RNA recovery did not vary significantly during the period studied (mean RNA recovery \pm 1 SD $=5.6 \pm 1.7$ $\mathrm{mg} / \mathrm{g}$ of liver, $n=198)$. The liver weight underwent a slight decrease during the first $5 \mathrm{~d}$ of life $(389 \pm 56 \mathrm{mg}$ at birth to $266 \pm 88 \mathrm{mg}$ at day 5), then it increased regularly to adult values.

Time course of pyruvate kinase gene expression in the liver of newborn and suckling rats. The pyruvate kinase mRNA level was very high in the liver of 18 - $d$-old fetuses. It decreased to low values in 20-d-old fetuses and remained unchanged during the suckling period from day 1 through day 15 . Then the specific mRNA increased: in the liver of 22-d-old weaned

Table I. Effects of Glucose Feeding and Bt 2 cAMP Administration on Liver L-type Pyruvate Kinase mRNA and cAMP Levels, Plasma Insulin, Plasma Glucagon, and Blood Glucose During Development as Compared with Age-Matched and Adult Controls

\begin{tabular}{|c|c|c|c|c|c|c|}
\hline & L-Type pyruvate kinase mRNA & $\begin{array}{l}\text { Blood } \\
\text { glucose }\end{array}$ & Plasma insulin & Plasma glucagon & $\begin{array}{l}\text { Insulin/glucagon } \\
\text { (molar ratio) }\end{array}$ & Liver cAMP \\
\hline & integration units & g/liter & $\mu U / m l$ & $p g / m l$ & & $\mathrm{nmol} / \mathrm{g}$ \\
\hline \multicolumn{7}{|l|}{ Controls $(n=7-10)$} \\
\hline Fetus at term & & $0.66 \pm 0.14$ & $73 \pm 23$ & $176 \pm 19$ & 9.5 & \\
\hline Hour 6 & & $0.65 \pm 0.09$ & $14 \pm 5$ & $326 \pm 37$ & 0.9 & \\
\hline Day 5 & $520 \pm 80$ & $0.97 \pm 0.05$ & $17 \pm 7$ & $389 \pm 21$ & 1 & $0.798 \pm 0.050$ \\
\hline Day 10 & $1,120 \pm 80$ & $1.16 \pm 0.07$ & $21 \pm 8$ & $263 \pm 11$ & 1.8 & \\
\hline Day 15 & $(413-1,830)$ & $1.13 \pm 0.09$ & $14 \pm 9$ & $265 \pm 45$ & 1.2 & \\
\hline Adults (postabsorptive) & $3,370 \pm 330$ & $1.06 \pm 0.13$ & $15 \pm 4$ & $49 \pm 4$ & 7.0 & \\
\hline \multicolumn{7}{|l|}{ Glucose-fed } \\
\hline Day $5(n=9)$ & $363 \pm 80$ & $1.84 \pm 0.25$ & $92 \pm 26$ & $220 \pm 18$ & 9.5 & $0.677 \pm 0.109$ \\
\hline Adults $(n=6)$ & $15,700 \pm 1,600$ & $1.07 \pm 0.18$ & $99.4 \pm 27$ & $23 \pm 10$ & 98 & $0.446 \pm 0.09$ \\
\hline \multicolumn{7}{|l|}{ cAMP-injected } \\
\hline Day $5(n=7)$ & $315 \pm 130$ & $0.97 \pm 0.13$ & - & - & - & - \\
\hline Day $10(n=7)$ & $403 \pm 145$ & $1.06 \pm 0.13$ & - & - & - & - \\
\hline Adults $(n=3)$ & $330 \pm 100$ & $1.63 \pm 0.3$ & - & - & - & - \\
\hline
\end{tabular}

Glucose, $\mathrm{Bt}_{2}$ cAMP, or saline was administered to 5- and 10-d-old suckling rats or adult rats as described in Methods. Fetuses and newborns aged $6 \mathrm{~h}$ were not injected. The specific mRNA was counted by the dot blot procedure, using a Shimadzu densitometer. Each value is the mean $\pm 1 \mathrm{SD}$ for at least three individual experiments, each experiment comprising three animals from the same litter. Each plasma glucagon or plasma insulin value is the mean \pm 1 SD for 7 to 10 animals. Adult controls were fed a standard chow diet (see Methods) and killed at 10 a.m. in the postabsorptive period. 


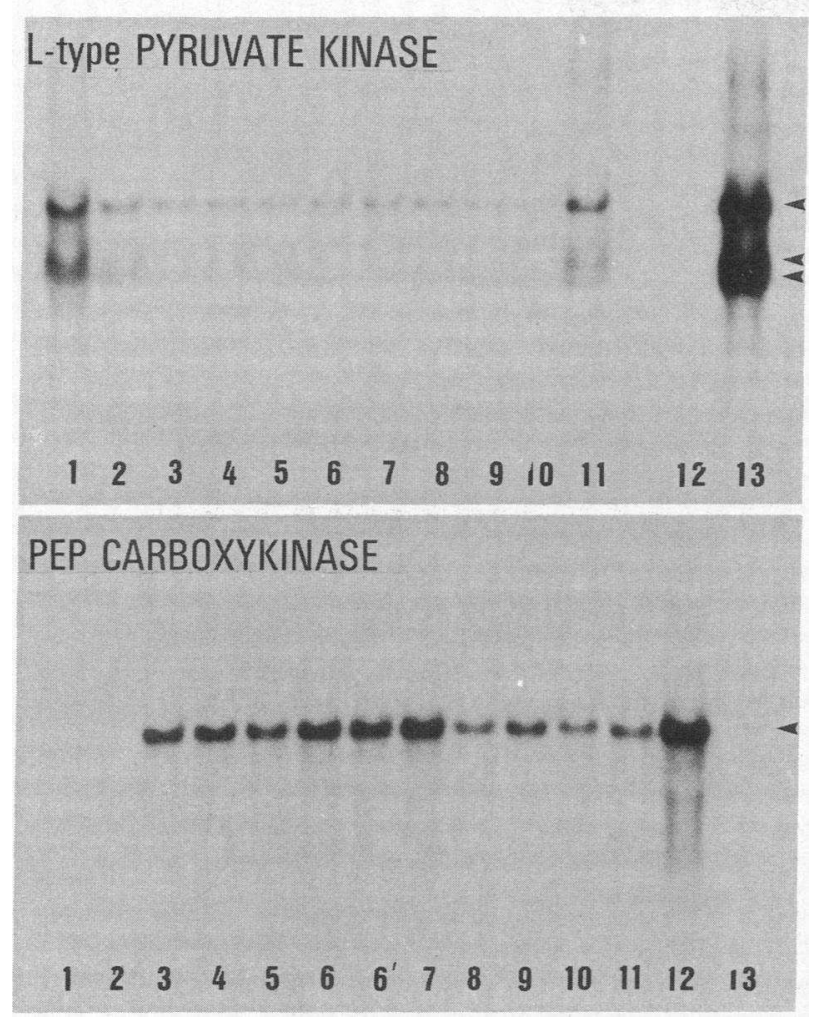

Figure 1. Northern blot analysis of L-type pyruvate kinase and PEP carboxykinase mRNAs in the developing rat liver. Total liver RNA $(30 \mu \mathrm{g}$ ) from fetuses 18 and $20 \mathrm{~d}$ after conception (lanes 1-2); newborn rats aged 1, 3, 6, 9, and $24 \mathrm{~h}$ (lanes 3-7); 5-, 10-, and 15-d-old suckling rats (lanes 8-10); 22-d-old weaned rat (lane 11); and adult controls that were either fasted $48 \mathrm{~h}$ (lane 12) or refed the carbohydrate-rich diet for $18 \mathrm{~h}$ after a 48-h fast (lane 13) were electrophoresed on vertical 10-mM methyl mercury hydroxide-agarose gels, blotted onto nylon filters, and hybridized with either a single-strand L-type pyruvate kinase probe or a randomly primed double-strand PEP carboxykinase probe. The presence of an equal amount of total RNA in each lane was checked by hybridizing the filters with a control cDNA probe (albumin, reference 33 ).

rats, the amount of specific mRNAs matched that found in adult controls fed the same chow diet (Figs. 1 and 2).

Fig. 1 shows that three pyruvate kinase mRNA species of $3.2,2.2$, and $2.0 \mathrm{~kb}$, respectively, hybridize to the probe, as reported by Marie et al. (25). A modification of the 3.2/2.2+ 2 $\mathrm{kb}$ mRNA ratio occurred during development, but the three RNA species underwent largely parallel changes during the entire period studied.

The level of pyruvate kinase gene transcription was high in liver nuclei of fetuses born at term by cesarean section (transcription rate $=68 \pm 20 \mathrm{ppm}$ ). The gene transcription rapidly decreased, reaching very low values within $24 \mathrm{~h}$ after birth (transcription rate $=15 \pm 7 \mathrm{ppm}$ ). It remained low during the first $10 \mathrm{~d}$ and increased to reach adult values in weaned rats (transcription rate $=50 \pm 10$ ppm; see Fig. 2).

The relative contribution of the $L$ and $L^{\prime}$ mRNAs in the above RNA quantitation deserves particular attention, especially as our pyruvate kinase cDNA probe hybridizes to both mRNA species. To address this issue, we carried out in vitro RNA translation analysis in the liver of fetuses and neonates. Fig. 3 shows the products of the cell-free translation of new-

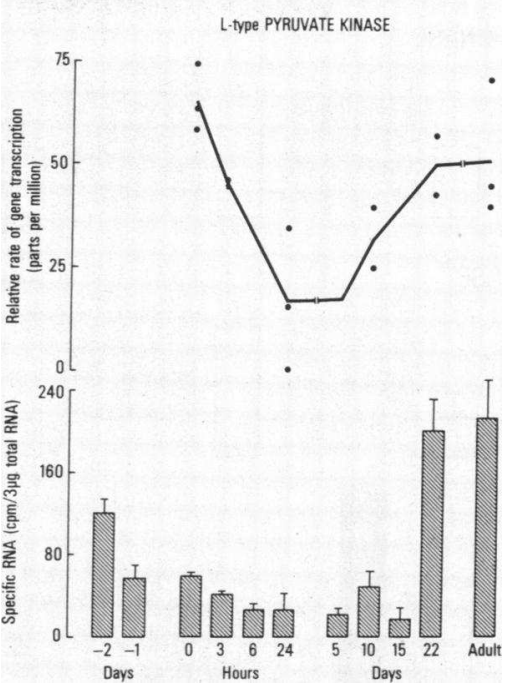

Figure 2. Time course of rat liver L-type pyruvate kinase gene transcription and mRNA content during development. L-Type pyruvate kinase gene transcription (upper curve) and mRNA content (hatched bars) were studied in the liver of fetuses and newborns (cesarean section), suckling or weaned rats, and in adult controls fed a standard chow diet. Ltype pyruvate kinase gene transcription is expressed in parts per million and the mRNA

content in counts per minute per $3 \mu \mathrm{g}$ total RNA. Each determination of the gene transcription is the mean for duplicate samples. Each value of mRNA determination is the mean \pm 1 SD for at least three determinations, each determination comprising a mean of three animals from the same litter.

born rat liver RNAs eluted from a microchromatographic immunoaffinity column carrying anti-L-type pyruvate kinase antibodies and analyzed on a polyacrylamide/SDS gel as described in Methods. The liver mRNAs from 15- and 18-d-old fetuses direct the synthesis of two polypeptides corresponding to $L$ and $L^{\prime}$-type pyruvate kinase $(60$ and $63 \mathrm{kD}$, respectively;

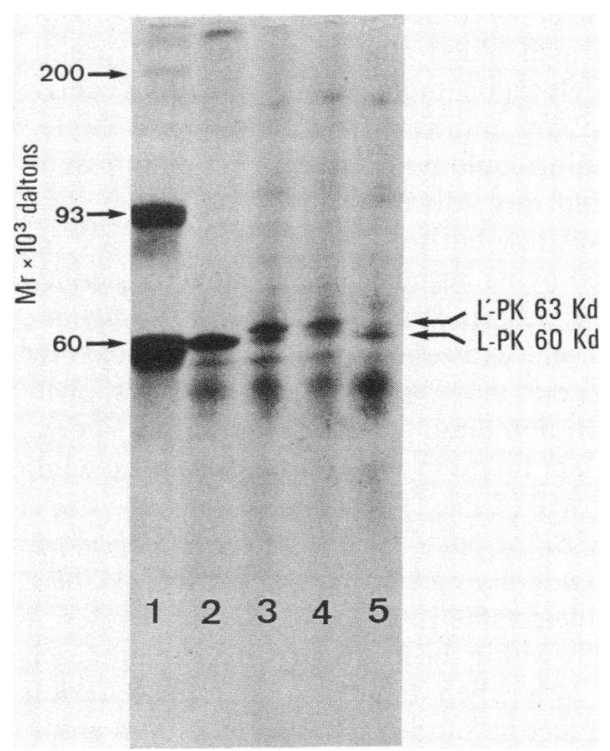

Figure 3. Analysis of in vitro-synthesized pyruvate kinase by SDSPAGE during development. Polyadenylated rat liver RNAs from fetuses 15 and $18 \mathrm{~d}$ after conception (lanes 3 and 4 ), a newborn aged 3 $\mathrm{h}$ (lane 5) and a fed adult control (lane 2) were translated in a rabbit reticulocyte cell-free system. In vitro-synthesized products were purified by immunoaffinity microchromatography on an anti-L-type pyruvate kinase antibody column and electrophoresed together with molecular weight markers (lane 1). L'-type (63 kD) and L-type (60 $\mathrm{kD})$ pyruvate kinase subunits are indicated by arrows. 


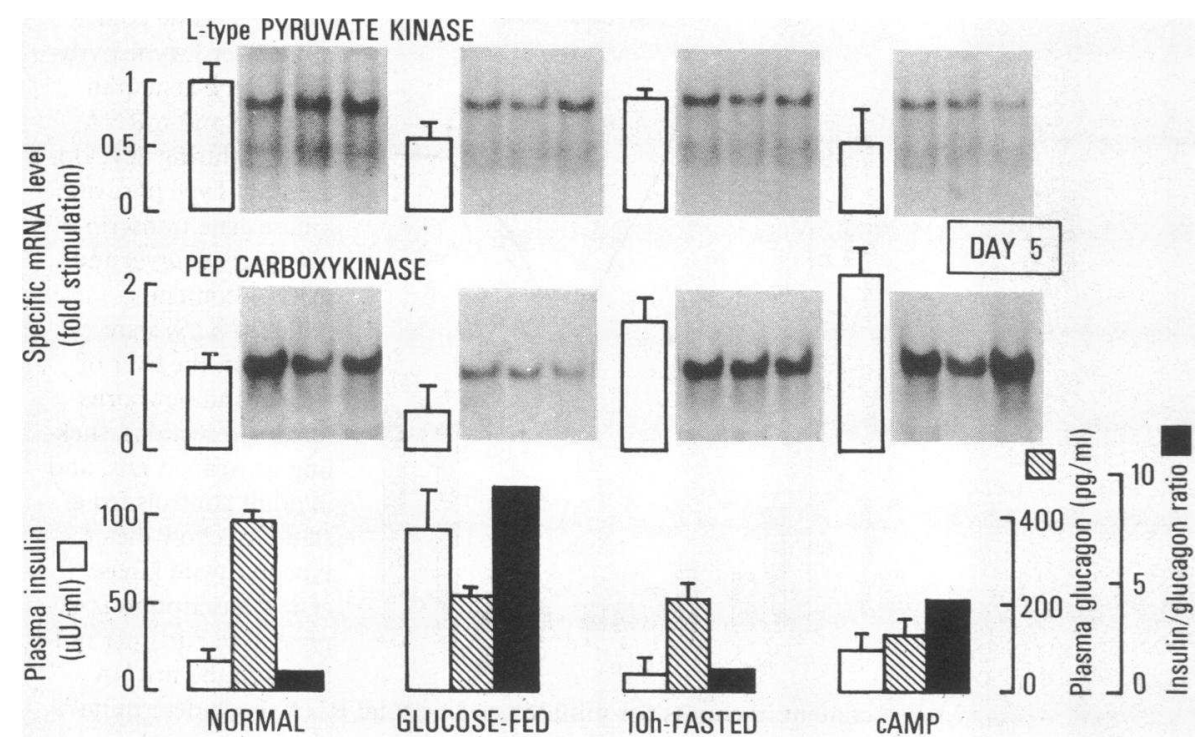

Figure 4. Effects of glucose feeding, 10-h fasting, and $\mathrm{Bt}_{2} \mathrm{cAMP}$ administration on liver L-type pyruvate kinase mRNA, PEP carboxykinase mRNA, blood glucose, plasma insulin, plasma glucagon, and the insulin/glucagon molar ratio in 5-d-old suckling rats. 5-d-old suckling rats were either glucose-fed or cAMP-injected (10 $\mu \mathrm{g}$ $\mathrm{Bt}_{2} \mathrm{CAMP} / \mathrm{g}$ body weight) every $3 \mathrm{~h}$ for 10 $h$, as described in Methods. Northern blot analysis of the RNAs was performed as described in Fig. 1 and the bands were scanned using a Shimadzu densitometer. Each lane corresponds to one individual experiment and the values presented are the mean \pm 1 SEM for at least three individual experiments. see Fig. 3, lanes 3 and 4 ). Fig. 3 also shows that the $L^{\prime}$ species is barely detectable at birth (lane 5).

Effects of glucose and CAMP on L-type pyruvate kinase gene expression in suckling animals. Fig. 1 shows that refeeding 48-h-fasted adult rats the carbohydrate-rich diet gives rise to a 100-fold accumulation of L-type pyruvate kinase mRNA in the liver, whereas the L-type pyruvate kinase mRNA is barely detectable in the liver of 48-h-fasted adult rats (34). In contrast, feeding either 5-d-old (Fig. 4 and Table I) or 10-d-old suckling rats (not shown) the glucose-rich diet, as described in Methods, did not increase and even decreased the specific mRNA level in the liver, as compared with age-matched controls. Thus, despite high blood glucose and plasma insulin levels, high insulin/glucagon molar ratio, and significantly lowered plasma glucagon and liver cAMP levels $(P<0.005$, Table I), glucose feeding could not trigger the gene expression in the liver of 5-d-old rats. Moreover, pyruvate kinase gene expression, which was low but readily detectable in suckling rats, was little altered by its negative effector. Indeed, neither fasting nor $\mathrm{Bt}_{2}$ cAMP administration could significantly reduce the low level of gene expression in the liver of 5-d-old rats (Fig. 4). In 10-d-old rats, however, both fasting (not shown) and CAMP administration inhibited gene expression to an extent that is close to that found in the liver of glucose-fed adult rats injected with cAMP (Table I).

Time course of PEP carboxykinase gene expression in the liver of normal neonates and suckling rats. PEP carboxykinase mRNA was barely detectable in 18- and 20-d-old fetuses; it then increased rapidly within the first hours after birth to reach maximum levels at $24 \mathrm{~h}$, when it matched that of fasted adult rats (Fig. 1). Full induction of the mRNA results from a dramatic activation of PEP carboxykinase gene transcription whose kinetics closely parallels the mRNA accumulation (transcription rate 175,700 , and $1,350 \pm 200 \mathrm{ppm}$ at 0,4 , and $24 \mathrm{~h}$ of life, respectively; see Fig. 5). Interestingly, after this intense stimulation of PEP carboxykinase gene expression in the newborn, both mRNA accumulation and gene transcription decreased in suckling rats. Fig. 5 shows that the transcription rates and mRNA levels in the liver were low at days 5 and 10 (transcription rate: $542 \pm 26$ ppm at day 10 ) as compared with that found at hour 6, while plasma glucagon and insulin remained largely unchanged (Table I).

Effects of glucose and CAMP on PEP carboxykinase gene expression in suckling animals. Refeeding 48-h-fasted adult rats the carbohydrate-rich diet blocks PEP carboxykinase gene expression in the liver, whereas fasting dramatically increases its expression, as reported by Hanson and colleagues (Fig. 1 and reference 25). In agreement with these data, we found that feeding suckling rats the glucose-rich diet described in Methods resulted in a low level of gene expression at day 5 (Fig. 4), 10, and 15 (not shown), while plasma insulin increased and plasma glucagon and liver cAMP decreased (Table I). Finally, both $10-\mathrm{h}$ fasting and cAMP administration to suckling rats resulted in a stimulation of gene expression whose extent, however, was less than that found in response to the physiological burst of glucagon that occurs at birth (Fig. 4).

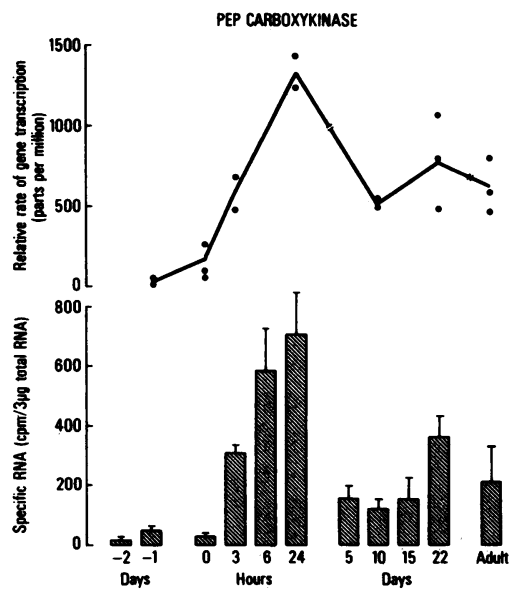

Figure 5. Time course of rat liver cytosolic PEP carboxykinase gene transcription and mRNA content during development. PEP carboxykinase gene transcription (upper curve) and mRNA content (hatched bars) were studied in the liver of fetuses and newborn (cesarean section), suckling and weaned rats, and in adult controls fed a standard chow diet and killed at 10 a.m. during the postabsorptive period. PEP carboxykinase gene transcription is expressed in parts per million and the mRNA content in counts per minute per $3 \mu \mathrm{g}$ total RNA. Each determination of the gene transcription is the mean for duplicate samples. Each value of mRNA determination is the mean \pm 1 SD for at least three determinations, each determination comprising a mean of three animals from the same litter. 


\section{Discussion}

L-type pyruvate kinase and PEP carboxykinase are two enzymes whose activities control the glycolytic and gluconeogenic fluxes in the liver. The regulation of the gene expression of both enzymes is known to occur at the transcriptional and the posttranscriptional levels in adults. Indeed, the carbohydrate-rich diet stimulates the transcription of the L-type pyruvate kinase gene and stabilizes its specific mRNAs $(35,4,5)$, whereas glucose feeding and insulin block the transcription of the PEP carboxykinase gene and shorten the half-life of its mRNAs $(13,36,37)$. Conversely, glucagon via its second messenger, cAMP, blocks L-type pyruvate kinase gene transcription, shortens the $t_{1 / 2}$ of the mRNA, and inactivates the enzyme by reversible phosphorylation at its catalytic site (4-9). Glucagon also stimulates PEP carboxykinase gene transcription and enhances the specific mRNA stability $(12,36)$.

These studies report only the short-term effects of glucose and pharmacological doses of glucagon (or cAMP) on gene expression in adult rats. The consequences of a prolonged physiological hyperglucagonemia on expression of the two genes, however, remain largely unknown. In this study, we focused on the effects of the long-term physiological hyperglucagonemia that occurs during the neonatal period.

At birth, major developmental and environmental changes occur in the liver. First, the liver stops being an erythropoietic tissue. Second, it becomes a gluconeogenic organ (38). The transplacental source of nutrients (comprising glucose and amino acids) is abruptly discontinued (39) and replaced by milk, which is a high-fat, low-carbohydrate diet (40). The activity of the key glycolytic enzyme in the liver, L-type pyruvate kinase, which is very active in fetal liver, decreases at birth (41, 42) while the activity of the key gluconeogenic enzyme, PEP carboxykinase, absent in the fetus, is immediately switched on so as to meet the glucose requirements of the neonate $(43,44)$. Simultaneously, plasma glucagon increases dramatically, whereas plasma insulin and the plasma insulin/glucagon molar ratio decrease (45). Both the gluconeogenic activity of the liver and the low plasma insulin/glucagon ratio last during the entire suckling period (46).

In this study we show that PEP carboxykinase mRNA, which is absent in the fetus, reaches very high values within the first hours of life. The mRNA accumulation results at least in part from a dramatic activation of the gene transcription, a feature that does not exclude other levels of regulation, namely mRNA stability. The full activation of gluconeogenesis in the newborn thus is a transcriptional phenomenon.

The activation of PEP carboxykinase gene expression parallels the physiological rise in plasma glucagon in the neonate. Indeed, both the mRNA level and plasma glucagon are low at birth in animals born by cesarean section at term and they increase rapidly in the newborn, peaking as soon as $1 \mathrm{~h}$ after delivery (Fig. 1). After birth, the PEP carboxykinase mRNA levels, the specific gene transcription, and the plasma glucagon levels undergo parallel changes during the first $24 \mathrm{~h}$ of life. It is difficult to ascertain whether the activation of gene expression results from hyperglucagonemia only or if other factors are also involved. Using a specific cDNA probe, however, Mencher et al. and Benvenisty et al. $(47,48)$ have shown that cAMP administration to 21-d-old fetuses results in a strong induction of PEP carboxykinase mRNA and its precursors, whereas insulin administered together with cAMP abolishes its stimulatory effect. On the other hand, glucose feeding in 5-dold rats reduces the gene expression, while plasma insulin and the plasma insulin/glucagon molar ratio dramatically increase. The PEP carboxykinase gene thus responds early to both its positive and negative effectors, namely glucagon and insulin; it is fully stimulated by glucagon at birth and adequately inhibited by insulin during suckling.

Interestingly, a discrepancy between plasma glucagon and PEP carboxykinase gene expression occurs at day 5. Indeed, both gene transcription and mRNA levels decrease during suckling, while plasma glucagon, insulin, and the insulin/glucagon molar ratio remain unchanged. In keeping with this, fasting or cAMP administration at day 5 results in only a 1.5to 2-fold stimulation of gene expression, a stimulation that is far less than that seen in adult controls (4.6- to 7-fold). Similar results were found at days 10 and 15 (data not shown).

The reason why the PEP carboxykinase gene does not respond adequately to cAMP at day 5 is unclear. Nevertheless, note that repeated administration of cAMP to adult rats results in first an attenuation, then an extinction of PEP carboxykinase gene transcription in adult rat liver $(12,36)$. In addition, Exton and colleagues already noted that the stimulation of hepatic gluconeogenesis by endogeneous glucagon is so high in suckling rats that neither fasting nor exogeneous glucagon could further increase PEP carboxykinase activity in the suckling period (49).

The reason why PEP carboxykinase activity remains high in suckling rats while its mRNA decreases also seems paradoxical. To account for the discrepancy between a high enzyme activity and a low level of specific mRNA, one can postulate either a regulation of $\mathrm{mRNA}$ translation (for instance by cAMP, as already shown for lactic dehydrogenase mRNA, reference 50 ), or a regulation of the protein stability during this period. Note that major modifications of the $t_{1 / 2}$ of the protein are known to occur in the neonatal period: almost no degradation of the protein is found during the first $36 \mathrm{~h}$ of life, and its $t_{1 / 2}$ has been reported to be relatively long in the first week, as compared with adult liver (mean $t_{1 / 2}$ in the first week was $12 \mathrm{~h}$ vs. $30-40 \mathrm{~min}$ to $4 \mathrm{~h}$ in adult liver, references 51 and 52).

Two pyruvate kinase species are present in fetal liver: the L-type pyruvate kinase, specific of liver differentiation, and the R-type pyruvate kinase, specific of erythroid differentiation. Both enzymes comprise four subunits, $L$ subunits for the $L$ isozyme, and $L^{\prime}$ subunits for the R-isozyme $(42,53)$. One single gene encodes the $L$ and $L^{\prime}$ subunits (54), which differ by their $\mathrm{NH}_{2}$ termini (55). Tanaka and co-workers have shown that the R-type isozyme is high in fetal liver and disappears at birth, when the erythroid cells of the liver disappear. The Ltype isozyme, also present in fetal liver, decreases at birth and remains low during the entire suckling period (42). Since liver L'-type pyruvate kinase mRNA is barely detectable at birth, as shown by our in vitro translation analysis, the alterations of pyruvate kinase mRNAs in the liver of newborn rats are due to modifications of L-type pyruvate kinase mRNA only.

We show here that the expression of the liver L-type pyruvate kinase gene is present at birth and rapidly decreases within the first hours of life. It remains low but detectable during the entire suckling period and it increases around day 15 , while the pups have access to the high-carbohydrate chow diet of the mother. The changes in the dietary status in this period are progressive and differ from rat to rat, accounting for the scattering of mRNA values in 15-d-old animals. 
The present study shows that the regulation of liver L-type pyruvate kinase gene expression in the newborn is mainly transcriptional, a feature that is not exclusive of other levels of regulation, namely the posttranscriptional level. Of course, one might regard the inhibition of the gene transcription in suckling rats as a consequence of their long-term physiological hyperglucagonemia, especially as glucagon is known to block gene expression in adults $(4,5,35)$. In fact, since dietary glucose did not trigger and even slightly decreased gene expression in 5- and 10-d-old rats (despite high plasma insulin levels and lowered plasma glucagon and liver cAMP levels as compared with age-matched controls), one might also consider an immaturity of the regulatory system of the gene in newborns. Along the same line, exogeneous cAMP in this period could not adequately block the gene expression either. Finally, the regulation of the L-type pyruvate kinase gene expression in newborn rat liver resembles that found in adult tissues that express the gene at a low constitutive level (e.g., kidney, reference 24).

\section{Acknowledgments}

We are especially thankful to Dr. Richard W. Hanson for his friendly discussions and comments and for providing us with the PEP carboxykinase cDNA probe. We wish to thank Dr. Joelle Marie and Dr. Marie-Pierre Simon, who initiated the study of L-type pyruvate kinase gene expression in fetal and newborn rat liver and Dr. Sophie Vaulont and Dr. Jean-François Decaux for constant stimulating discussions. We thank Mrs. Monique Poussière for typing this manuscript and Mr. Alan Strickland for his help in preparing it.

This work was supported by the Institut National de la Santé et de la Recherche Médicale and the Centre National de la Recherche Scientifique. S. Lyonnet was the recipient of grants from the Fondation Française pour la Nutrition and the Fondation pour la Recherche Médicale.

\section{References}

1. Cladaras, C., and G. L. Cottam. 1980. Dietary alteration of translatable mRNA sequences acting for rat liver pyruvate kinase. $J$. Biol. Chem. 255:11499-11503.

2. Shrago, E., J. W. Young, and H. A. Lardy. 1967. Carbohydrate supply as a regulator of rat liver phosphoenolpyruvate carboxykinase activity. Science (Wash. DC). 158:1572-1576.

3. Johnson, M. L., and C. M. Veneziale. 1980. Hormonal regulation of liver pyruvate kinase concentration and activity. Biochemistry. 19:2191-2195.

4. Vaulont, S., A. Munnich, J. Marie, G. Reach, A. L. Pichard, M. P. Simon, C. Besmond, P. Barbry, and A. Kahn. 1984. Cyclic AMP as a transcriptional inhibitor of upper eukaryotic gene transcription. Biochem. Biophys. Res. Commun. 125:135-141.

5. Vaulont, S., A. Munnich, J. F. Decaux, and A. Kahn. 1986. Transcriptional and post-transcriptional regulation of L-type pyruvate kinase gene expression in rat liver. J. Biol. Chem. 261:7621-7625.

6. Ljunstrom, O., L. Berglund, and L. Engstrom. 1976. Studies on the kinetic effects of adenosine-3':5'-monophosphate-dependent phosphorylation of purified pig-liver pyruvate kinase type L. Eur. J. Biochem. 68:497-506.

7. Ekman, P., U. Dahlqvist, E. Humble, and L. Engstrom. 1976. Comparative kinetic studies on the L-type pyruvate kinase from rat liver and the enzyme phosphorylated by cyclic 3',5'-AMP-stimulated protein kinase. Biochim. Biophys. Acta. 429:374-382.

8. Ishibashi, H., and G. L. Cottam. 1978. Cyclic AMP-stimulated phosphorylation of liver pyruvate kinase in hepatocytes. Biochem. Biophys. Res. Commun. 85:900-905.

9. Ishibashi, H., and G. L. Cottam. 1978. Glucagon-stimulated phosphorylation of pyruvate kinase in hepatocytes. J. Biol. Chem. 253:8767-8771.

10. Tilghman, S. M., R. W. Hanson, L. Reshef, M. F. Hopgood, and F. J. Ballard. 1974. Rapid loss of translatable messenger RNA of phosphoenolpyruvate carboxykinase during glucose repression in liver. Proc. Natl. Acad. Sci. USA. 71:1304-1309.

11. Reshef, L., and R. W. Hanson. 1972. The interaction of catecholamines and adrenal corticosteroids in the induction of phosphoenolpyruvate carboxylase in rat liver and adipose tissue. Biochem. J. 127:809-814.

12. Lamers, H., R. W. Hanson, and H. M. Meisner. 1982. cAMP stimulates transcription of the gene for cytosolic phosphoenolpyruvate carboxykinase in rat liver nuclei. Proc. Natl. Acad. Sci. USA. 79:5137-5141.

13. Granner, D., T. Andreone, K. Sasaki, and F. Beale. 1983. Inhibition of transcription of the phosphoenolpyruvate carboxykinase gene by insulin. Nature (Lond.). 305:549-551.

14. Inoue, H., T. Noguchi, and T. Tanaka. 1984. Rapid regulation of L-type pyruvate kinase mRNA by fructose in diabetic rat liver. $J$. Biochem. (Tokyo). 96:1457-1462.

15. Ogier, H., A. Munnich, S. Lyonnet, G. Reach, and A. Kahn. 1987. Dietary and hormonal regulation of L-type pyruvate kinase gene expression in rat small intestine. Eur. J. Biochem. 166:365-370.

16. Cox, R. A. 1968. The use of guanidinium chloride in the isolation of nucleic acids. Methods Enzymol. 12:120-129.

17. Aviv, H., and P. Leder. 1972. Purification of biologically active globin messenger RNA by chromatography on oligothymidilique acid-cellulose. Proc. Natl. Acad. Sci. USA. 69:1408-1412.

18. Pelhman, M. R. B., and R. J. Jackson. 1974. An efficient mRNA-dependent translation system from reticulocyte lysates. Eur. $J$. Biochem. 46:83-88.

19. Kahn, A., D. Cottreau, D. Daegelen, and J. C. Dreyfus. 1981. Cell-free translation of messenger RNAs from adult and fetal human muscle. Characterization of neosynthesized glycogen phosphorylase, phosphofructokinase and glucose phosphate isomerase. Eur. J. Biochem. 116:7-12.

20. Laemmli, U. K. 1970. Cleavage of structural proteins during the assembly of the head of bacteriophage T4. Nature (Lond.). 227:680-685.

21. Bailey, J. M., and M. Davidson. 1976. Methylmercury as a reversible denaturing agent of agarose gel electrophoresis. Anal. Biochem. 70:75-85.

22. Thomas, P. S. 1980. Hybridization of denatured RNA and small DNA fragments transferred to nitrocellulose. Proc. Natl. Acad. Sci. USA. 77:5201-5205.

23. Munnich, A., C. Besmond, S. Darquy, G. Reach, S. Vaulont, J. C. Dreyfus, and A. Kahn. 1985. Dietary and hormonal regulation of aldolase B gene expression. J. Clin. Invest. 75:1045-1052.

24. Simon, M. P., C. Besmond, D. Cottreau, A. Weber, P. Chaumet-Riffaud, J. C. Dreyfus, J. Sala-Trepat, J. Marie, and A. Kahn. 1983. Molecular cloning of cDNA for rat L-type pyruvate kinase and aldolase B. J. Biol. Chem. 258:14576-14584.

25. Marie, J., M. P. Simon, Y. C. Lone, M. Cognet, and A. Kahn. 1986. Tissue-specific heterogeneity of the $3^{\prime}$-untranslated region of L-type pyruvate kinase mRNAs. Eur. J. Biochem. 158:33-41.

26. Messing, J. 1983. New M13 vectors for cloning. Methods Enzymol. 101:20-79.

27. Church, G. M., and W. Gilbert. 1984. Genomic sequencing. Proc. Natl. Acad. Sci. USA. 81:1991-1995.

28. Yoo-Warren, M., M. A. Cimbala, K. Felz, J. E. Monahan, J. P. Leis, and R. W. Hanson. 1981. Identification of a DNA clone to phosphoenolpyruvate carboxykinase (GTP) from rat cytosol. J. Biol. Chem. 256:10224-10227.

29. Feinberg, A. P., and B. Vogelstein. 1983. A technique for radiolabeling DNA restriction endonuclease fragments to high specific activity. Anal. Biochem. 132:6-13.

30. Reeder, R. H., and R. G. Roeder. 1972. Ribosomal RNA synthesis in isolated nuclei. J. Mol. Biol. 67:433-441. 
31. Zylber, E. A., and S. Penman. 1971. Products of RNA polymerase in the HeLa cell nuclei. Proc. Natl. Acad. Sci. USA. 68:2861-2865.

32. Schibler, U., A. Hagenbuchle, P. K. Wellauer, and A. C. Pittet. 1983. Two promoters of different strength control the transcription of the mouse alpha-amylase gene Amy-1 $1^{2}$ in the parotid gland and the liver. Cell. 33:501-508.

33. Sargent, T. D., J. R. Wu, J. Sala-Trepat, R. B. Wallace, A. A. Reyes, and J. Bonner. 1979. The rat serum albumin gene: analysis of cloned sequences. Proc. Natl. Acad. Sci. USA. 76:3256-3260.

34. Weber, A., J. Marie, D. Cottreau, M. P. Simon, C. Besmond, J. C. Dreyfus, and A. Kahn. 1984. Dietary control of aldolase B and L-type pyruvate kinase mRNAs in rat. J. Biol. Chem. 259:1798-1802.

35. Munnich, A., J. Marie, G. Reach, S. Vaulont, M. P. Simon, and A. Kahn. 1984. In vivo hormonal control of L-type pyruvate kinase gene expression. J. Biol. Chem. 259:10228-10231.

36. Sasaki, K., T. P. Cripe, S. R. Koch, T. L. Andreone, D. D. Petersen, E. G. Beale, and D. K. Granner. 1984. Multihormonal regulation of phosphoenolpyruvate carboxykinase gene transcription. $J$. Biol. Chem. 259:15242-15251.

37. Cimbala, M. A., W. H. Lamers, K. Nelson, J. E. Monahan, H. Yoo-Warren, and R. W. Hanson. 1982. Rapid changes in the concentration of phosphoenolpyruvate carboxykinase mRNA in rat liver and kidney. J. Biol. Chem. 257:7629-7636.

38. Girard, J. 1986. Gluconeogenesis in late fetal and early neonatal life. Biol. Neonate. 50:237-258.

39. Girard, J., and P. Ferré. 1982. Metabolic and hormonal changes around birth. In Biochemical Development of the Fetus and the Neonate. C. T. Jones, editor. Elsevier/North Holland, Amsterdam. 517-551.

40. Luckey, T. D., T. J. Mende, and J. Pleasant. 1954. The physical and chemical characterization of rat's milk. J. Nutr. 54:345-349.

41. Vernon, R. G., and D. G. Walker. 1968. Changes in activity of some enzymes involved in glucose utilization and formation in developing rat liver. Biochem. J. 106:321-329.

42. Saheki, S., K. Harada, Y. Sanno, and T. Tanaka. 1978. Hybrid isozymes of rat pyruvate kinase. Their subunit structure and developmental changes in the liver. Biochim. Biophys. Acta. 526:116-128.

43. Ballard, F. J., and R. W. Hanson. 1967. Phosphoenolpyruvate carboxykinase and pyruvate carboxylase in developing rat liver. Biochem. J. 104:866-871.

44. Hue, L., and J. Girard. 1986. Gluconeogenesis and its regulation in isolated and cultured hepatocytes. In Research in Isolated and
Cultured Hepatocytes. A. Guillouzo and F. Gueguen-Guillouzo, editors. John Libbey Eurotext Ltd/INSERM, London/Paris. 63-86.

45. Girard, J. R., G. S. Cuendet, F. B. Marliss, A. Kervran, M. Rieutort, and R. Assan. 1973. Fuels, hormones, and liver metabolism at term and during the early postnatal period in the rat. J. Clin. Invest. 52:3190-3200.

46. Girard, J. R., P. Ferré, A. Kervran, J. P. Pegorier, and R. Assan. 1977. Role of the insulin/glucagon ratio in the changes of hepatic metabolism during development of the rat. In Glucagon: Its Role in Physiology and Clinical Medicine. P. P. Foa, J. S. Baja, and N. L. Foa, editors. Springer-Verlag, New York. 563-581.

47. Mencher, D., H. Cohen, N. Benvenisty, O. Meyuhas, and L. Reshef. 1984. Primary activation of cytosolic phosphoenolpyruvate carboxykinase gene in fetal rat liver and the biogenesis of its mRNA. Eur. J. Biochem. 141:199-203.

48. Benvenisty, N., E. B. Simchon, H. Cohen, D. Mencher, O. Meyuhas, and L. Reshef. 1983. Control of the activity of phosphoenolpyruvate carboxykinase and the level of its mRNA in the liver of newborn rats. Eur. J. Biochem. 132:6663-6668.

49. Beaudry, M. A., J. L. Chiasson, and J. H. Exton. 1977. Gluconeogenesis in the suckling rat. Am. J. Physiol. 233:E175-E180.

50. Jungmann, R. A., A. I. Constantinou, S. P. Squinto, J. KwastWelfeld, and J. S. Schwette. 1986. Regulation of lactate dehydrogenase gene expression by cAMP-dependent protein kinase subunits. Ann. NY Acad. Sci. 478:147-161.

51. Hanson, R. W., L. Reshef, and F. J. Ballard. 1975. Hormonal regulation of hepatic phenolpyruvate carboxykinase (GTP) during development. Fed. Proc. 34:166-171.

52. Tilgham, S. M., R. W. Hanson, and F. J. Ballard. 1976. Hormonal regulation of phosphoenlpyruvate carboxykinase (GTP) in mammalian tissues. In Gluconeogenesis. R. W. Hanson and M. A. Mehlman, editors. John Wiley \& Sons, Inc., New York. 47-91.

53. Marie, J., M. J. Levin, M. P. Simon, and A. Kahn. 1983. Genetic and epigenetic control of the pyruvate kinase isozymes in mammals. Isozymes. 7:221-240.

54. Marie, J., M. P. Simon, J. C. Dreyfus, and A. Kahn. 1981. One gene, but two messenger $R N A s$ encode liver $L$ and red cell $L$ ' pyruvate kinase subunits. Nature (Lond.). 292:70-72.

55. Lone, Y. C., M. P. Simon, A. Kahn, and J. Marie. 1986. Complete nucleotide and deduced amino acid sequences of rat L-type pyruvate kinase. FEBS (Fed. Eur. Biochem. Soc.) Lett. 195:97-100. 